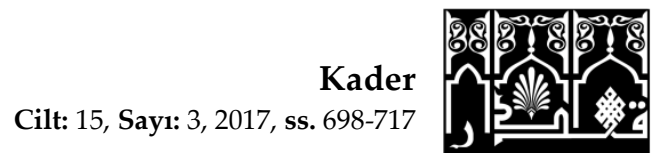

\title{
A HISTORICAL CASE STUDY: HUMAN BODY AS A VISUAL FIELD IN $18^{\mathrm{TH}}$ CENTURY ANATOMY
}

\author{
Mesut Malik YAVUZ \\ Dr., Istanbul Medeniyet U. Political Science and Public Administration Dpt. \\ malikyavuz@yahoo.com \\ https://orcid.org/0000-0002-6580-2093
}

\begin{abstract}
I will attempt to provide a historical case study in this article where I suggest that the demarcation between perception and how a figure is 'seen' is the process of perpetual filtering. I argue that this filtering operates through the basic visual principles, which may vary and have divergent functions in different paradigms. This historical case study will focus on the work of William Cheselden, to reveal the paradigm-based filtering in these prints by arguing that the sense data is organized in the simplest manner to view figures in their unity. I will focus on the visual principle of simplicity, which features the patterns of similarity, contrast and symmetry. I will conclude that these visual principles were used by Chelselden to achieve perfection by conveying right proportions of scales of human body since his observations was laden-with Newtonian-paradigm. Finally, I will conclude that these findings would enable an inter-disciplinary study to disclose Kalam as a theo-centric science discipline.
\end{abstract}

Keywords: Human body, visual principles, perfection, simplicity, filtering.

\section{TARIHSEL BİR VAKA ÇALIŞMASI: 18. YÜZYIL ANATOMISİNDE BİR GÖRSEL ALAN OLARAK İNSAN BEDENI}

\section{Öz}

Burada, içinde bir figürün görülmesi ile algılanması arasındaki sınır belirleniminin duyumsama ve algılama arasındaki sürekli filtreleme süreci olduğunu savunacağım bir tarihsel vaka çalışması sunmaya çalışacağım. Bu filtrelemenin, farklı paradigmalarda farklılık gösterip, farklı işlevlere sahip olması mümkün temel görsel ilkeler aracılığıyla işlediği iddiasında bulunacağım. Bu tarihsel vaka çalışması, Londralı ünlü cerrah William Cheselden'in insan iskeletine ait 66 şilte içeren etkili eserine odaklanarak bu nüshalardaki paradigma-temelli filtrelemeyi, duyu verilerinin figürü bütünlügüyle gösterebilmek için en basit biçimde organize edildiğini savunarak ortaya koyacaktır. Burada kullanılan görsel ilkenin benzerlik, karşıtlık ve simetri kalıplarını içeren, basitlik olduğunu göstereceğim. Cheselden'in kullandığı görsel ilkelerin, onun gözlemlerinin Newton paradigması ile dolu olduğundan, insan bedenindeki ölçeklerin doğru sayısını ve doğru orantılarını aksettirerek mükemmelliğe erişmeye çalıştığı sonucuna varacağım. Nihayetinde, bu sonuçların Kelam'ın Tanrı ile Yaratılış arasındaki ilişkiyi açıklamayı amaç edinen nesnel bilişsel içeriğe sahip ilahiyat temelli bilimsel bir araştırma programı olarak ortaya konmasında ileride disiplinler arası bir çalışmaya imkan tanıyacağını vurguladım.

Anahtar Kelimeler: İnsan bedeni, görsel ilkeler, mükemmellik, basitlik, filtreleme.

Atıf: Yavuz, Mesut Malik. "A Historical Case Study: Human Body As A Visual Field In $18^{\text {th }}$ Century Anatomy". Kader 15, sy. 3 (2017): 698-717.

Geliş Tarihi: 15.11.2017 Kabul Tarihi: 22.12.2017 $\quad$ Doi: $10.18317 /$ kaderdergi.353385




\section{Introduction}

The term seeing has been central in the issues related to the discussions concerning the nature of one's visual interactions with his/her surrounding reality since Ancient Greeks although it has been subjected to changes on its way to the Enlightenment. Ancient philosophers paid great attention to the word 'theoria' which means "to contemplate" or to "take a look at", in their attempts to come up with epistemological explanations about the relationship between the subject and object of perception. Although the etymological analysis of the Greek equivalent of the term theory discloses that knowing was a particular way of seeing. In this etymological sense, one can observe the implication that a theory is based on how we see the world. Plato used the act of seeing in his 'Allegory of Cave' to demonstrate the need to transcend sensation in terms of avoiding deception in the pursuit of truth, so that we need to see what is beyond this deceptive perception. In this regard, ancient philosophers used it to talk about a hierarchy between different levels of human knowledge: sensation and perception. However, if there is a dichotomy between sensation and perception, this requires an exploration of the question 'what is the relationship between perception and how a figure is 'seen?', and the further question: 'is a theory based on a particular way of seeing or a particular way of perceiving'?

The same dichotomy between the word and image represented the dichotomy between truth and deception through the middle ages. However, with the Enlightenment, during the $18^{\text {th }}$ century the triumph of Newtonian mathematics and axiomatic science gave a new impetus to the Neoplatonic desire for exactness in the knowledge of inexact things. ${ }^{2}$ In a similar vein, I argue that by the emergence of the Enlightenment, how we 'see' the world was considered being shaped by the theory we have about our surroundings. This is tantamount to saying that the visual field, which surrounds us, is filled with theory. In other words, our perception is theory-laden. In this regard, it is reasonable to argue in the context of medicine that, "the development of animal anatomy during the $18^{\text {th }} \mathrm{cc}$. was perfectly paralleled by a motivation in the engraving technique of the scientific illustrators to illustrate a simple and assimilable truth". ${ }^{3}$ Thus, it is congruent to argue that as products of the illustrators' interactions with their visual field, scientific illustrations might be instrumental to explore the relationship between perception and how a figure is 'seen'. I will use William Cheselden's work titled 'Anatomy of the Humane Body' in this paper as a primary source to demonstrate

1 The word theoria, Greek correspondent of the English word 'theory', is derived from the $\theta \varepsilon \dot{\varepsilon} \alpha$ (a view) + ó $\tilde{\alpha} v$ (to see). Thus, seeing has a pivotal impact on the ancient thinking concerning the interactions between the perceiving subject and perceived object.

2 B. M. Stafford, Body Criticism: Imaging the Unseen in Enlightenment Art and Medicine, (Cambridge: MIT Press, 1993), 11.

3 B. Ford, Scientific Illustration in the Eighteenth Century, R. Porter (ed) The Cambridge History of Science vol. 4 Eighteenth Century, (Cambridge: Cambridge University Press, 2003), 576. 
that his illustrations were the instruments to reflect the human body as a meaningful whole.

Hence, this article will use visual culture to dig deeper into the conceptual underpinnings of eighteenth century anatomy. I will focus on the prints featured in the above-mentioned work of Cheselden, to argue that he used the perceptual principles of symmetry and similarity to depict body parts on the page and that this visual form of representation mirrored the conceptual unity that he 'saw' in the human body as a whole. To demonstrate this, firstly, I will argue that the sense data is organized in the simplest manner in Cheselden's illustrations to enable readers in terms of perceiving figures in their unity, which will be later related to the maxim of Gestalt principle (in the fourth section) that the whole is other than the sum of its parts. Secondly, the principles of grouping by similarity, contrast and symmetry will be analysed as particular patterns of simplicity to suggest the view that Cheselden's illustrations used these principles to justify that every bone in human body is united to one another through a structure. Moreover, the notion of human body will be related to the concept of perfection that incorporates the structures of simplicity and symmetry. Finally, it will be concluded that human body and thereby the illustrations of Cheselden can be perceived in their unity by the reinforcing visual principles, which helps Cheselden to achieve the notion of perfection by conveying the right proportions in human body. I will compare this to the principles used by Ibn Sinna in his work Canon of Medicine. I will conclude that this comparison would enable us to comprehend how human body is represented as a visual field through the filter of paradigmatic differences.

\section{Sensation, Perception and Visual Field}

Divergent epistemic status given to sensing and perceiving is a function of the value that is assigned to the truth seeking process. In this regard, "the English scientists' enormous intellectual influence throughout the $18^{\text {th }}$ century reinforced Neo-platonic view of low degree of reality belonging to matter, and by analogy, to physical or sensory impressions". ${ }^{4}$ The same conception can be attributed validly to the positivists of the post-modern era. However, the advocates of this position neglect the view that sensation and perception are also mixed and intermingled processes that "one cannot straightly do one without involving the others". ${ }^{5}$ Thus, an analysis of perception is not sufficient on its own to conceive the interaction of the subject and object of the perception within the visual field.

Sensation is only one of the significant processes in point in terms of revealing the conceptual underpinnings of the relationship between the subject (the knower) and the object (the known). In this regard, sensation is the first point of access - but not as a distinct one - for the subject (the knower) to relate with the visual field since "all the minds of all living thinking organisms are prisoners that must rely on

4 B. M. Stafford, Body Criticism: Imaging the Unseen in Enlightenment Art and Medicine, (Cambridge: MIT Press, 1993), 420.

5 B. M. Stafford, Body Criticism: Imaging the Unseen in Enlightenment Art and Medicine, (Cambridge: MIT Press, 1993), 429. 
information smuggled in to them by the senses" ${ }^{6}$ This does not imply that sensation is a process that limits the perception of a subject. Rather, this points to the fact that sensory stimulation provides the data for our hypotheses about the nature of the external world, and it is those hypotheses that form our perceptions of the world. ${ }^{7}$ Thus, to use an analogy, sensation provides the raw material for the production of the knowledge about the external world. In this regard, producing knowledge contains and transcends perception. Describing constitution of visual knowledge in such a manner requires a particular organization between these intermingled levels of interaction with the visual field.

We can find one salient definition of perception as "a mental construction of the outside world: for example your perception of two words on this page is something that your brain has constructed from lots of coded electrical impulses from your eye" ${ }^{8}$ This is tantamount to saying that understanding is combining present perceptions to the previous ones. Thus, the subject chooses which object to perceive within the visual field since the object is constituted in the subject. However, this choice is made according to the patterns discovered in the visual field in the sense that there are relational structures in the visual field that enables this constitution. Thus, perception is the conscious experience of objects and object relations. ${ }^{9}$ In this regard, the reference made to conscious experience reveals the transformation from the ancient conception of visual knowledge to that of the modern era.

The emergence of the role of visual culture reveals the function of figures in perceiving objects. However, it is reasonable to argue in this regard that the nature of perceived figure depends on the character of surrounding field, which may comprise not only a simple ground but also other figure..$^{10}$ Thus, the patterns and structures in the visual field are instrumental to provide a valid explanation of the relationship between sensation and perception. This calls for the question 'what kind of field organization yields to these patterns?'

The concept of perceptual organization is central to the following key question with regard to perception. "How does a subject leap from the information detected by his/her sensory receptors, which some theories based on the Platonic hierarchy hold to be incomplete or at least ambiguous, to his/her perceptions of the world, which are typically accurate, unambiguous and phenomenologically complete". ${ }^{11}$ There are many objects in the visual field of a cognitive subject and these objects have many sensory details; however when a cognitive subject sees an object, it is not other object's details but the details of that object are seen. In this regard, it is reasonable to argue that seeing is determined through one's eyes that a certain

\footnotetext{
S. Coren, Sensation and Perception. (Fort Worth TX: Harcourt Brace Colleague Publishers, 1994), 4.

S. Coren, Sensation and Perception. (Fort Worth TX: Harcourt Brace Colleague Publishers, 1994), 7.

A. Slater, and J. Oates, 'Sensation to Perception', in Oates, J. Grayson A. and Wood C. (eds.) Psychological Development and Early Childhood, (Milton Keynes: Open University Press, 2005), 93.

S. Coren, Sensation and Perception. (Fort Worth TX: Harcourt Brace Colleague Publishers, 1994), 12.

G. W. Hartmann, Gestalt Psychology, (New York: The Ronald Press Company, 1935), 100.

K. R. Boff, (eds.). Handbook of Perception and Human Performance. (New York: Wiley, 1986), 36-2.
} 
thing is present at a certain place. ${ }^{12}$ However, vision is different from seeing in terms of being an active exploration rather than passive recording. ${ }^{13}$ Thus, perception is a selective process that contains seeing as the provider of raw material. This points out to the claim that perception is grasping the structural features from this visual field.

Thus, the perceptual organization is a function of the way the sense data is acquired from the visual field. This brings the discussion to the crucial notion that "it is the particular arrangement, patterning, or organization of the parts into perceptual whole that determines the appearance and identity of a stimulus" ${ }^{14}$ In this particular arrangement, "any stimulus pattern tends to be seen in such a way that the resulting structure is as simple as the given conditions permit. ${ }^{15}$ This claim requires an analysis of the role of the notions of simplicity and perception in the discussion of visual objects, and human body, in particular, in this historical case study.

\section{Anatomy of the Bones and Simplicity}

\subsection{Simplicity and Perfection}

Simplicity is one of the significant issues in point on the discussion of scientific explanation, since according to early modern epistemic values, the simpler the scientific explanation, the better its scientific value is. In this regard, scientific clarity is one of the major factors behind the drive towards simplicity in the modern scientists. Furthermore, this can be inferred from the methodology, in which history is measured by befores and afters. In the modern world, "scientific illustration is replete with images designed to impress the public with a sense of unattainable complexity rather than to illuminate a simple truth". ${ }^{16}$ However, "in the $18^{\text {th }}$ century viewers enjoyed a respite from the complex illustrations of scientific matters due to the wonder of the scientists and their appreciation of representing reality in a scientifically perfect manner. ${ }^{17}$ Thus, the images in the studies of $18^{\text {th }}$ century represents a notion of wonder and the transformation of this wonder into a figure is realized through the eyes of the scientists of the century.

The notion of perfection is another significant case in point on the discussion of scientific illustrations. Knoeff claims that almost all anatomists of early modern era were professing to aim at perfection. ${ }^{18}$ Although perfection was the shared aim of the illustrators of almost all $18^{\text {th }}$ century anatomists, the approach held by these

12 R. Arnheim, Art and Visual Perception: A Psychology of the Creative Eye, (California: UCP, 1974), 32.

13 R. Arnheim, Art and Visual Perception: A Psychology of the Creative Eye, (California: UCP, 1974), 33.

K. R. Boff, (eds.). Handbook of Perception and Human Performance. (New York: Wiley, 1986), 36-7.

R. Arnheim, Art and Visual Perception: A Psychology of the Creative Eye, (California: UCP, 1974), 53.

16 B. Ford, Scientific Illustration in the Eighteenth Century, R. Porter (ed) The Cambridge History of Science vol. 4 Eighteenth Century, (Cambridge: Cambridge University Press, 2003), 564.

17 B. Ford, Scientific Illustration in the Eighteenth Century, R. Porter (ed) The Cambridge History of Science vol. 4 Eighteenth Century, (Cambridge: Cambridge University Press, 2003), 565.

18 R. Knoeff, 'Moral Lessons of Perfection', O P Grell (ed) Medicine and Religion in Early Modern Europe, (Hampshire: Ashgate, 2007), 121. 
anatomists varies at different levels. For, "the concept of perfection can and has to be defined according to the assumptions of the author employing the concept". ${ }^{19}$ Thus, it might be instrumental to analyse the way the author sees the figure in front of him/her that is to be represented in the illustrations. Moreover, achieving perfection in the illustrations of human body depends on the usage of the simplicity since this can be demonstrated only through the proper arrangement of the bones of human body, and the resulting structure is as simple as the given conditions permit.

Cheselden's 'The Anatomy of Bones', which is a standard work of reference from $18^{\text {th }}$ century, was intended to be a comprehensive system of human anatomy. ${ }^{20}$ In the $18^{\text {th }}$ century, the new thirst for knowledge based on the Enlightenment gave "impetus to new ways of communicating the realities of science". ${ }^{21}$ Moreover, the simplest way "to use space to communicate is to arrange or rearrange the things in it". ${ }^{22}$ Before Cheselden's work, the manuscripts of medieval era were the source of reference to apply in case of human anatomy. However, "the decorative manuscripts of the medieval era were no longer enough, and the demand for books brought the technology that in turn drove the interest in scientific illustration". ${ }^{23}$ In this regard, the impulse to generate visual knowledge paved the way for using figures as a whole via the arrangement of their parts.

The emerging notion of wonder under the era of Enlightenment also points out to a significant function of scientific illustrations that is the recording of the state of human understanding of the era. ${ }^{24}$ Moreover, it is reasonable to argue that in the era of enlightenment the human body represented "the ultimate visual compendium and also as the organizing structure of structures"..$^{25} 18^{\text {th }}$ century anatomists, Overcoup and Bantekoe, argued that all laws governing the body are the same as those that govern the rest of the universe. ${ }^{26}$ Thus, we can refer to Cheselden's work as a recording of the Enlightenment thinking with regard to the role of bones in human body. Moreover, I argue that the patterns of simplicity is instrumental to comprehend the relationship between perception and how a figure is 'seen' - which is human body in Cheselden's work in our case - since these patterns reinforce the unity of the structure of human body.

19 R. Knoeff, 'Moral Lessons of Perfection', O P Grell (ed) Medicine and Religion in Early Modern Europe, (Hampshire: Ashgate, 2007), 143.

20 B. Harrison, and H. C. G. Matthew, (eds.), Oxford Dictionary of National Biography, (Oxford: Oxford University Press, 2004), 315.

21 B. Ford, Images of Science: A History of Scientific Illustrations, (London: British Library, 1992), 4.

22 B. Trevsky, Visualizing Thought, Topics in Cognitive Science 3 (3) (2010): 499- 535, p. 504.

23 B. Ford, Images of Science: A History of Scientific Illustrations, (London: British Library, 1992), 4.

24 B. Ford, Images of Science: A History of Scientific Illustrations, (London: British Library, 1992), 2.

25 B. M. Stafford, Body Criticism: Imaging the Unseen in Enlightenment Art and Medicine, (Cambridge: MIT Press, 1993), 12.

26 L. J. Israel, 'Enlightenment, Radical Enlightenment and the Medical Revolution of the Late Seventeenth and Eighteenth Centuries', O P Grell (ed) Medicine and Religion in Early Modern Europe, (Hampshire: Ashgate, 2007), 9. 
One strong claim a defender of the above-mentioned position might often adopt is that interactions within our visual field demonstrate correlations with the principles of simplicity. Although, at prima facie, the principle of simplicity might seem to be a basic one, the determination of simplicity through the analysis of the shapes requires a question of 'how'? Is it the number of elements in a figure that constitutes the simplicity or is there another force? A reply to these questions is instrumental in analysing the notion of simplicity in the Cheselden's work since I will take the shapes of the bones and human body - as a figure - drawn in his illustrations as reference to this analysis. Arnheim argues that through "the structural features, not the number of elements in a figure", a good definition of simplicity can be provided. ${ }^{27}$ This means that "perceptual forces, in relation to the visual field, will organize themselves in the simplest, most regular and most symmetrical pattern available" ${ }^{28}$ Thus, it is necessary to reply the following questions 'Does the structure of the bones represent a pattern of simplicity?' and 'if so, how this is achieved?' I will demonstrate, in the next section, that the visual principles of similarity, contrast and symmetry are three ways to achieve simplicity and perfection, which are two notions of focus in the $18^{\text {th }}$ century anatomy.

\subsection{Similarity, Contrast and Symmetry}

\subsubsection{Similarity}

One of the key notions in point on the discussion of simplicity is the principle of grouping by similarity. In this regard, "the process of transforming the subtle realism of Nature", or human body for this case, into an engraver's line "imposes constraints and conventions of its own". ${ }^{29}$ Cheselden argues that it is useless to make long descriptions, since one view of such prints has the function of showing more than the fullest and best description can possibly do. ${ }^{30}$ Actually, this is reinforced by the use of camera-obscura in his work. Chelselden is the first person to have used the camera obsucra to gain precision in his illustrations, and the vignette on the title page shows him using this instrument. ${ }^{31}$ Thus, a scientific illustration is a mirror of the contemporaneous preoccupations and approach of the engraver. ${ }^{32}$ In this regard, it can be expected that, the Enlightenment paradigm's most significant feature - namely simplicity - will be reflected on Cheselden's prints about human skeleton.

I agree that instead of providing full descriptions for human anatomy, Cheselden demonstrates the scope of the human body to the fullest extent by using the conventions of simplicity through the principle of grouping by similarity. For,

27 R. Arnheim, Art and Visual Perception: A Psychology of the Creative Eye, (California: UCP, 1974), 57.

28 R. Arnheim, Art and Visual Perception: A Psychology of the Creative Eye, (California: UCP, 1974), 68.

29 B. Ford, Scientific Illustration in the Eighteenth Century, R. Porter (ed) The Cambridge History of Science vol. 4 Eighteenth Century, (Cambridge: Cambridge University Press, 2003), 561.

30 K. B Roberts, The Fabric of the Body, (Oxford: Clarendon Press, 1990), 424.

31 J. M. Norman, (ed.) Morton's Medical Bibliography: An Annotated Checklist of Texts Illustrating the History of Medicine. $5^{\text {th }}$ edition, (Aldershot: Scholar Press, 1991), 78.

32 B. Ford, Scientific Illustration in the Eighteenth Century, R. Porter (ed) The Cambridge History of Science vol. 4 Eighteenth Century, (Cambridge: Cambridge University Press, 2003), 561. 
structural features (shape, size, colour etc.) must be determined for the total pattern since the relations between parts depend on the structure of the whole..$^{33} \mathrm{In}$ the case of human body, these relations can be envisioned through the principles of grouping by similarity of the structural patterns. This is much more salient in the version dedicated to the Queen ${ }^{34}$, since there are also outline diagrams for many of the illustrations that contain notations by which the figures were interpreted. To see these patterns, which are actually present in the illustrations, an analysis of plates themselves is required with the discussion of these patterns.

The claim that the conventions of simplicity can be implemented by the principles of grouping by similarity is in itself a response to the question 'What is the simplest way of organizing the structure?' For, by this claim it is argued that the conventions organize a wealth of meaning and form in an overall structure that clearly defines the place and function of every detail in the whole. ${ }^{35}$ This is the case for the Chelselden's 'The Anatomy of Bones' since he argues that, in his introductory notes to the reader, "every bone in the human body here delineated as large as life and again reduced to lesser scales in order to show them united to one another". ${ }^{36}$ Thus, it can be defended that "the unity of the artist's conception leads to a simplicity that far from being incompatible with complexity, and shows its virtue only in mastering the abundance of human experience rather than escaping to the poverty of abstinence" ${ }^{37}$ For, human body can be compared to a complex machine although its perception can be operated through the simple structural relations of this united whole by using the principles of grouping by similarity, contrast and symmetry.

The first element of grouping principles by similarity that reinforces the notion of simplicity in Cheselden's illustrations is the continuity of the shape. In his thirteenth plate, Cheselden illustrates the spine of a human.

33 R. Arnheim, Art and Visual Perception: A Psychology of the Creative Eye, (California: UCP, 1974), 57.

34 This is the version used for this essay as the primary source.

35 R. Arnheim, Art and Visual Perception: A Psychology of the Creative Eye, (California: UCP, 1974), 60.

36 W. Cheselden, Osteographia, or The anatomy of the bones. By William Cheselden surgeon to Her Majesty; F.R.S. Surgeon to St. Thomas's Hospital, and Member of The Royal Academy of Surgery, (London : [s.n.], MDCCXXXIII, 1733), 62.

37 R. Arnheim, Art and Visual Perception: A Psychology of the Creative Eye, (California: UCP, 1974), 60. 


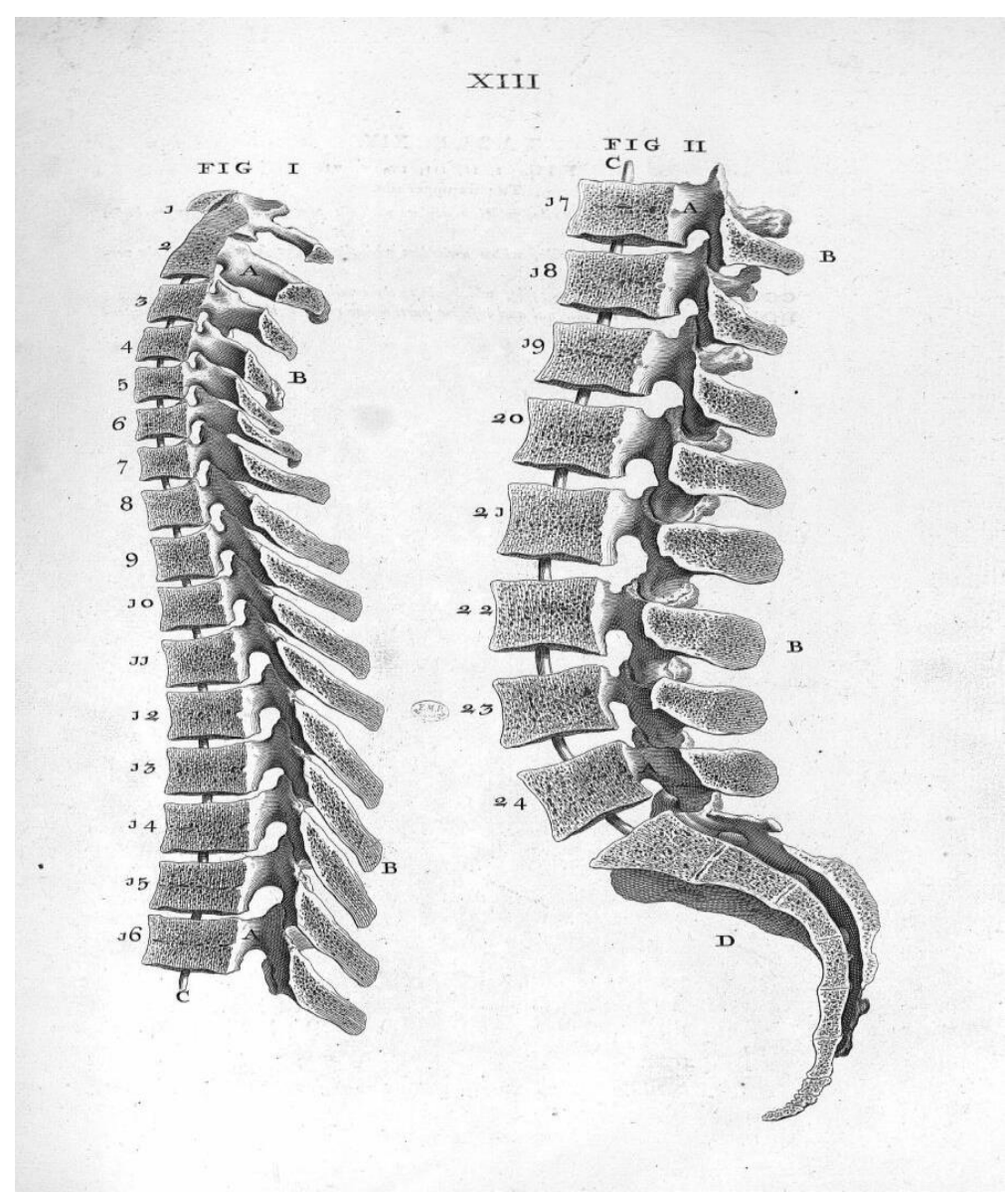

Plate 13, Cheselden's Anatomy of the Bones

For the thirteenth plate, Cheselden argues- in the Chapter III- that the bodies of vertebrae are all in the same manner connected by strong intervening ligaments and cartilages. ${ }^{38}$ In the Table XIII, it can be seen that Cheselden gives every vertebrae a number. There are sixteen vertebrae in the superior part (Figure I) and there are additional eight vertebrae for the remaining part (Figure II). However, the numbers are in a sequence from 1 to 24 starting with the first vertebrae in Figure I and ending with the last vertebrae of Figure II. This is a crucial point since there is a thin bone behind these bones (vertebrae) and although in the illustration this bone is intercepted by the spongy ligaments, it can be easily perceived as a distinct continuous bone not only for the first image but also for the both images in the Plate 13 due to the pattern of the continuity of the shape. Chesleden reinforces this pattern with the help of the usage of the numbers in Table XIII. Thus, there is a filtering process between the instant a figure is seen and perceived; and this filtering process is reinforced by the pattern of continuity of shape in this case.

38 W. Cheselden, Osteographia, or The anatomy of the bones. By William Cheselden surgeon to Her Majesty; F.R.S. Surgeon to St. Thomas's Hospital, and Member of The Royal Academy of Surgery, (London : [s.n.], MDCCXXXIII, 1733), 84. 
The last but not least element of grouping principles by similarity that is present in the illustrations of Cheselden is the direction of movement. This is a significant pattern, since Cheselden states that the actions of all the skeletons both human and comparative as well as the attitudes of every bone were his own choice. ${ }^{39} \mathrm{~A}$ salient example of the usage of this pattern is in the Plate 36, in which Cheselden chooses to illustrate the side view of a skeleton of a very robust man.

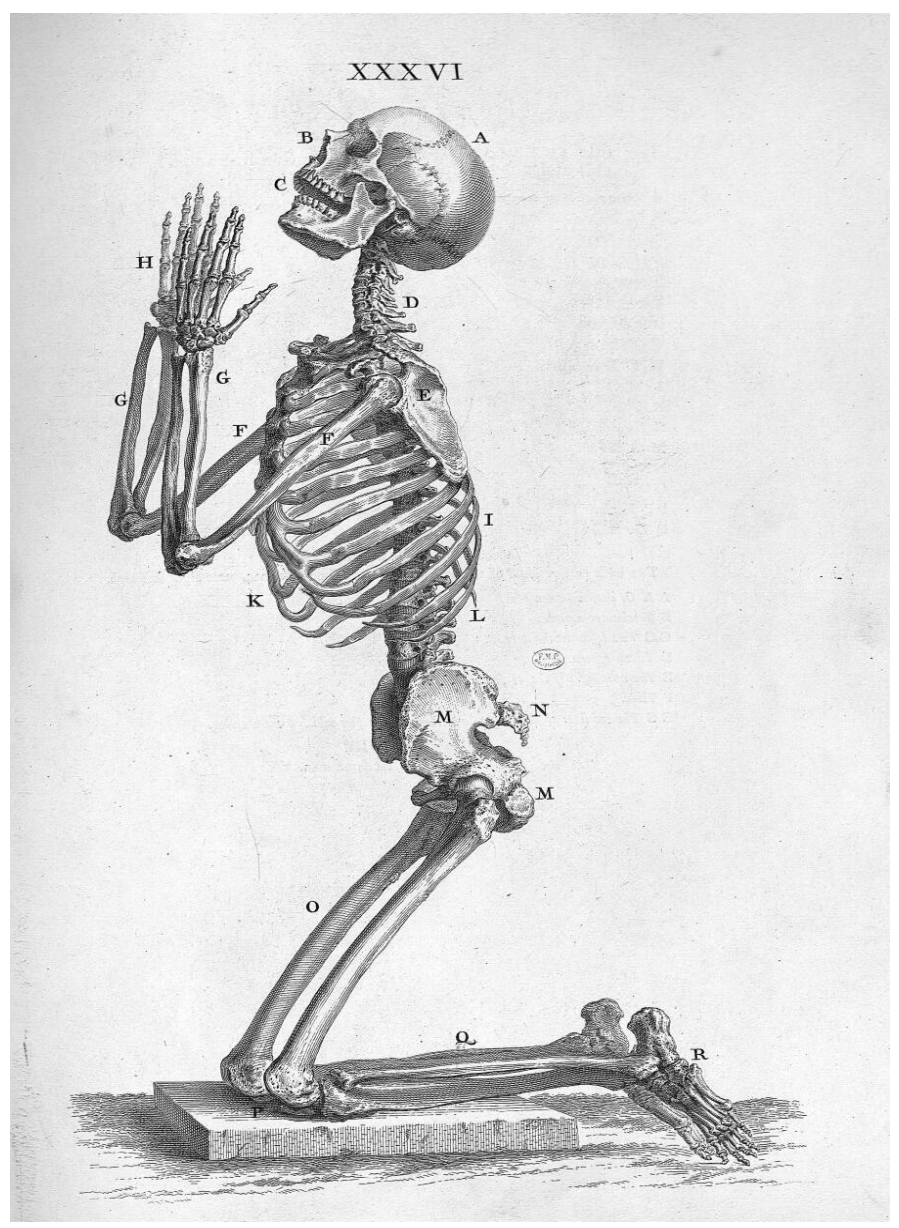

Plate 36, Anatomy of the Bones

Cheselden states that the skeleton is put into this attitude to represent the figure of human body in a larger scale. ${ }^{40}$ However, this illustration is replete with the principles of similarity and simplicity mentioned above. The continuity of shape is present with the help of usage of difference of brightness in the area of ribs and spine. Also, the hands are discernible with the usage of the pattern of direction of movement. In the case of an absence of this pattern, the hands would not be discernible and this would have led to an ambiguity in perception of human body.

39 K. B Roberts, The Fabric of the Body, (Oxford: Clarendon Press, 1990), 426.

40 W. Cheselden, Osteographia, or The anatomy of the bones. By William Cheselden surgeon to Her Majesty; F.R.S. Surgeon to St. Thomas's Hospital, and Member of The Royal Academy of Surgery, (London : [s.n.], MDCCXXXIII, 1733), 181. 


\subsubsection{Contrast}

Another visual principle that reinforces the notion of simplicity in Chelselden's illustrations is the visual principle of grouping by contrast. The Plate 19 has a figure that shows the anterior view of the trunk of a skeleton.

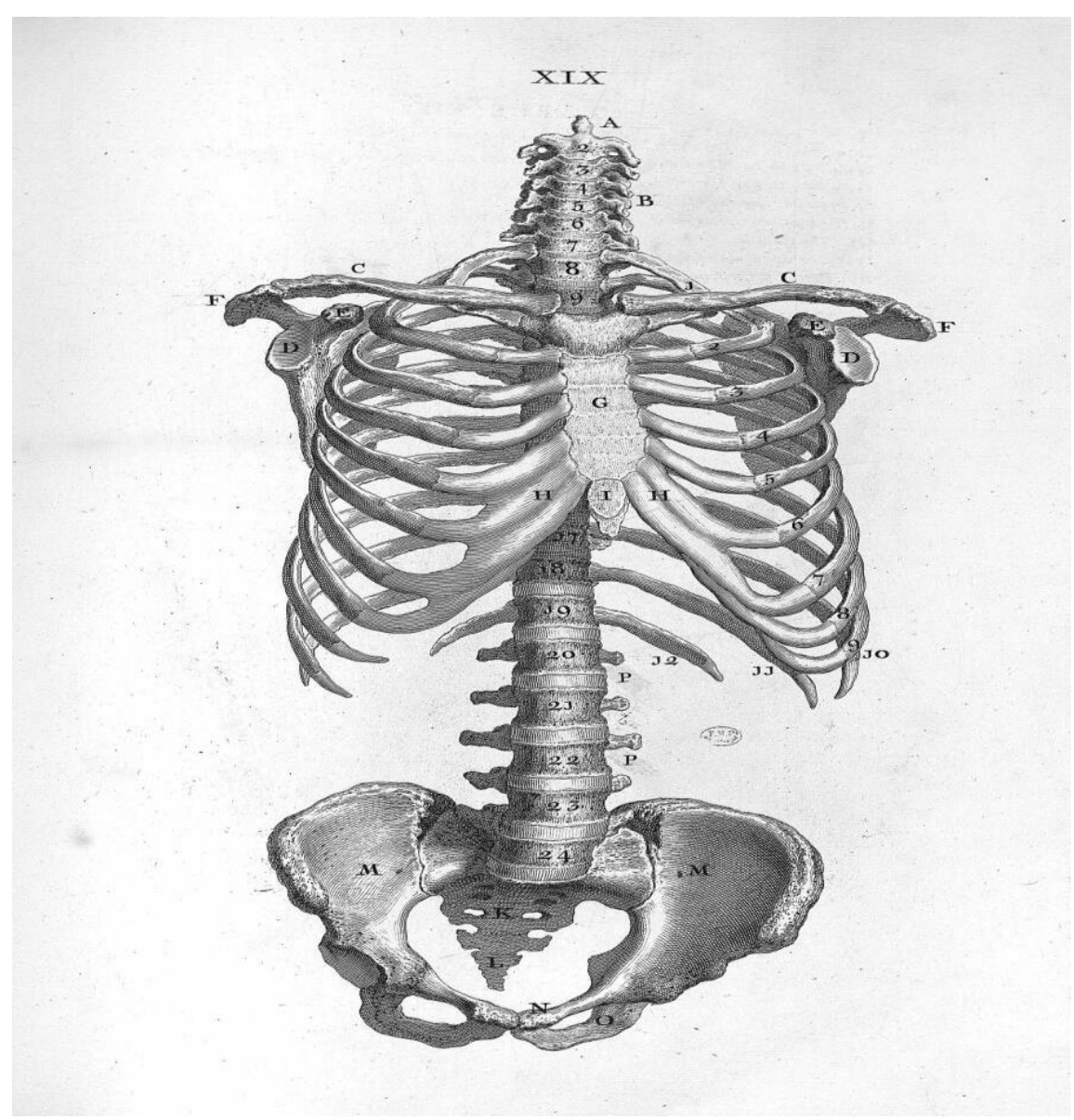

Once again twenty three of the vertebrae are numbered in a sequence in the Table XIX, and the ones that cannot be seen due to the obstruction of the bone of sternum are not numbered. However, this time the sequence is also interrupted after the $9^{\text {th }}$ vertebrae till $17^{\text {th }}$ one. This is a stronger usage of continuity of shape with the help of another visual principle of grouping by contrast. For, the bone of sternum is illustrated brighter than the bones of vertebrae. This helps the viewer to discern the spine from the sternum and also to trace the spine in a clear manner. The grouping of two distinct bones would not be possible, if the difference of brightness were not present. For, it is the principle of contrast that collects the spine as one part and the sternum as another in the perception of the figure.

Another figure that demonstrates the usage of contrast to illustrate the integrity of body is in the Plate 36 (Please see above). As has been mentioned above, the hands can be discerned by two visual principles: one is the contrast and the other is direction of the bones of the two distinct hands. Since, the contrast is not a 
sufficient pattern to discern the hands, Cheselden wisely chooses the skeleton in that attitude so that the direction of the bones of the fingers might be instrumental to perceive them as distinct hands. Working together with the principles of grouping by similarity, usage of contrast helps Cheselden to show the unity of bones without any ambiguity although the perception of the relation of bones might be a complex issue without the visual principles of simplicity. For, complexity brings ambiguity with it if there is no organizing structure in this complexity.

\subsubsection{Symmetry}

Symmetry is the next visual principle that reinforces the notion of simplicity in the illustrations of human body in Cheselden's work. One salient figure that represents the usage of symmetry as a visual principle of simplicity in this work can be found in Plate 25 (Please see below). Two figures of hand are shown in this plate by the principle of simplicity through the usage of symmetry. Cheselden argues that carpus is composed of eight bones of very irregular forms, undoubtedly the most proper that can be; yet why in these forms, rather than any other, no one was able to show..$^{41}$ Although the carpus is composed is irregular bones, the illustration helps the viewer to perceive two hands by putting them in a symmetrical position.

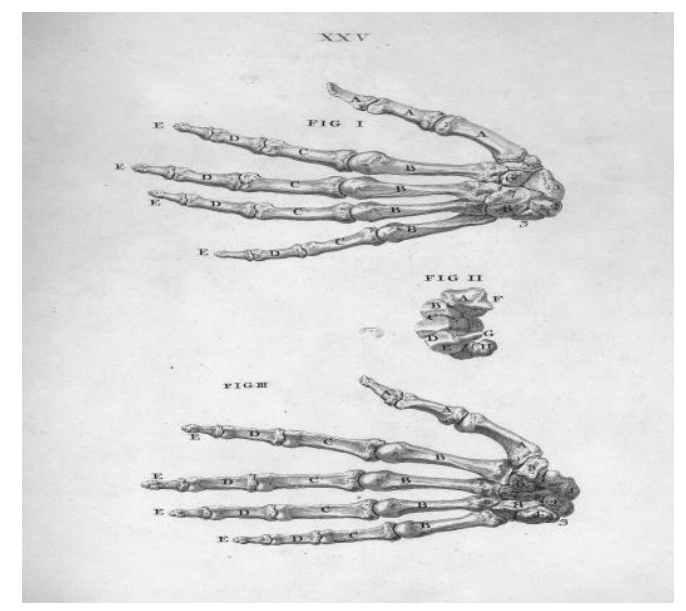

Plate 26, Anatomy of the Bones

In this regard, it is reasonable to argue that "comparisons, connections and separations cannot be made between unrelated things, but only when the setup as a whole suggests a sufficient basis". ${ }^{42}$ For, symmetry is used wherever it is available; if there is any other simpler pattern available then it will be the percept rather than symmetry. ${ }^{43}$ Since there is not any other simpler pattern available for the corpus of the hand, Cheselden uses the principle of symmetry to provide the

41 W. Cheselden, Osteographia, or The anatomy of the bones. By William Cheselden surgeon to Her Majesty; F.R.S. Surgeon to St. Thomas's Hospital, and Member of The Royal Academy of Surgery, (London : [s.n.], MDCCXXXIII, 1733), 90.

42 R. Arnheim, Art and Visual Perception: A Psychology of the Creative Eye, (California: UCP, 1974), 79.

43 R. Arnheim, Art and Visual Perception: A Psychology of the Creative Eye, (California: UCP, 1974), 95. 
viewer a meaningful whole. In the Table XXV, each bone of the corpus is assigned with a number and each bone of the fingers is notated with a letter. This usage of letters and numbers can be conceived as a reflection of the principle of symmetry. For, in the Plate 25, it seems that as if there were a horizontal axis as the centre of a symmetrical division between the two hands that leads the viewer to perceive the hands in the simplest structure obtainable within the given figure. This simplicity helps the viewer to discern two hands and also to perceive the structure that of the human hand.

Another salient figure that represents the usage of symmetry as a principle of simplicity is shown in the Plate 29, in which Cheselden presents the bones of the foot.

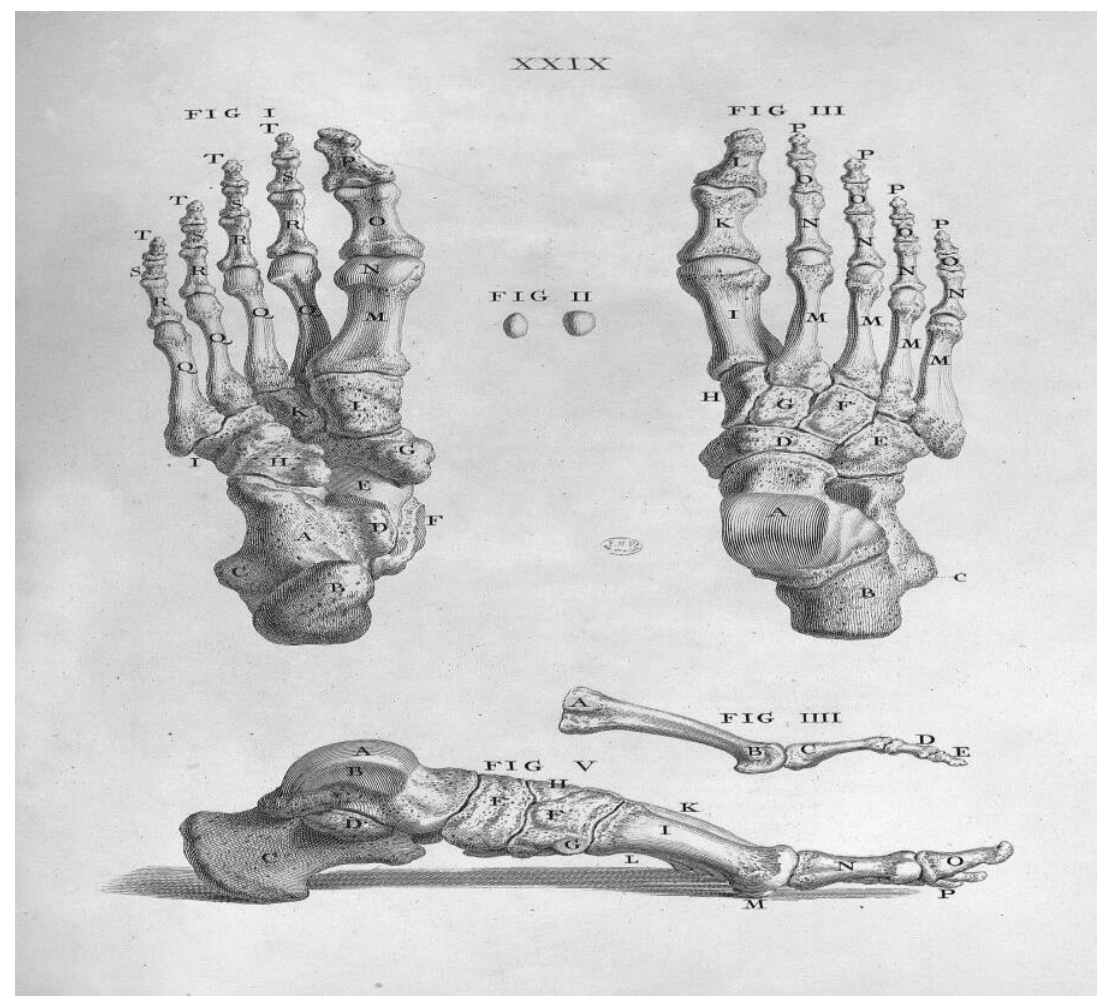

Plate 29, Anatomy of the Bones

Once again, the righht foot is exposed in two figures, which show the underside of the bones of the foot and the upper side of the bones of the foot side by side. However, this time the figures are seen in a way as if there were a vertical axis as the centre of a symmetrical division between the two views of the foot. This helps the viewer to comprehend the bones of the foot from different perspectives, but still as the figures of the same foot. Thus, symmetry is used by Cheselden to point the relationship between the perception and the way a figure is 'seen'.

Plate 36 is another case in point on the discussion of the usage of symmetry to reinforce the idea of Cheselden that every bone in human body is united to one another through a structure (please see the figure above). The pattern of symmetry 
is used both horizontally for the ribs and vertically for the bones of the legs in this figure. Moreover, the suture in the scull is made by the mutual indention of one bone with another, which is another example of the usage of symmetry. The usage of symmetry by Cheselden is also instrumental to understand his aim to achieve perfection. For, it can be claimed that European convention aimed at conveying right proportions, the correct number of scales, the alignment of petals in right order in $18^{\text {th }}$ century. ${ }^{44}$ The usage of symmetry - both horizontally and vertically helps the viewer to understand Cheselden's attempt to view the bones in the right proportions since when Cheselden reduced the ratio of the bones to a lesser scale, there is no other parameter that he could have applied other than the symmetry of the bones. This provides Cheselden to reach a level of perfection. For, $18^{\text {th }}$ century was an era of science to mature in scientific illustrations, in which "its findings came to a state of representational perfection that something exceeded the standards in modern reference sources". ${ }^{45}$ In this regard, my claim that the way a figure is seen depends on the paradigmatic attitudes of its era, is in line with this comparison. Since, while the sense data - human body and skeleton in our case study - remains fixed, its illustrations vary to the perceptual standards held in different periods.

My claim that visual knowledge is deeply rooted to the theory-laden perception of the particular figures, is corroborated by the obvious difference between medieval and modern descriptions with regard to the anatomy of the bones. Firstly, according to Ball, the work of Hippocrates depends on speculative ideas rather than empirical observations made on the body. ${ }^{46}$ This might be partly a function of the ontological significance given to soul over body during the classical times. However, Aristotle's contributions enabled physicians to hold teleological approach in medicine as well. In this regard, the relation between structure and function was the subject matter of the classical medical literature in the similar sense that "Galen regards the anatomy as the expression of the nature". ${ }^{47}$ In his anatomical descriptions, Ibn Sīnā follows teleological principles, which influence the way he 'sees' the human bones. ${ }^{48}$ This function-based approach was valid for Islamic anatomy from $9^{\text {th }}$ to $12^{\text {th }}$ century as was it case for the anatomy in the Western World during the time. ${ }^{49}$ This was partly due to the fact that dissection of human bodies was forbidden in Islam, but mostly it was a function of the conjectural signposting that lead Ibn Sinnā to adopt a function-based approach when depicting human bones. For, on the one hand, human skeleton would still be

44 B. Ford, Scientific Illustration in the Eighteenth Century, R. Porter (ed) The Cambridge History of Science vol. 4 Eighteenth Century, (Cambridge: Cambridge University Press, 2003), 562.

45 B. Ford, Scientific Illustration in the Eighteenth Century, R. Porter (ed) The Cambridge History of Science vol. 4 Eighteenth Century, (Cambridge: Cambridge University Press, 2003), 563.

46 K. H. Keskinbora, et. al. A systematic review of Ibn Sīnā's studies: reflections on anatomy, European Journal of Anatomy 20 (1) (2016): 99-100, p.99.

47 Ibn Sinā, A treatise on the Canon of medicine of Avicenna, incorporating a translation of the first book. (London :Luzac \& co., 1930), 104.

48 H. F. Batirel, Early Islamic Physicians and Throax. The Annals of Thoracic Surgery 67 (2) (1999) : 578580, p. 598.

49 P. Prioreschi, Anatomy in Medieval Islam, JISHIM 5 (2006): 2-6, s.2. 
accessible after someone passed away, which would eliminate the influence of Islam's prohibition of dissection; and on the other hand "human skeleton seemed to medieval anatomist deceptively simple and self-evident in ways that less visible structures did not". ${ }^{50}$ However, this simplicity was not aimed at perfection as a consequence of perceptual filtering rather it was aimed at demonstrating functional features of the skeleton.

In this regard, the descriptions of human skeleton gives us an idea of the motive to demonstrate the functional features of the skeleton. Ibn Sinna expresses "an association between the size and shape of a vertebra and its functions", which enables him "to consider the spine in sub-sections: cervical, thoracic, lumbar, sacral and coccygeal" ${ }^{51}$ However, this function-based approach led him to provide some inaccurate information on C2 and T12 vertebrae, as well as on the number of sacral vertebrae. ${ }^{52}$ For, although human skeleton remains the same, namely the sense data does not change, the knowledge derived from this sense data is a reflection of the theory-laden filtering of the data. However we see that "the biomechanical characteristics of the vertebrae and the spine are successfully delineated" in terms of reflecting Ibn Sīnā's function-based approach at its best; in a similar vein, "his view on the biomechanical properties on the craniovertebral junction is remarkable". ${ }^{53}$ In this regard, "the different characteristics of atlas and axis are very well defined" since they are instrumental to disclose their unique function in the sense that "the head-atlas segment is responsible for tilting the head toward the sides, while C0-C2 segment allows backward-forward movement." 54 Thus, the success of the descriptions with regard to human anatomy depend on the fulfilment of the principles held and arriving at the aims on basis of these principles. However, although the principles followed by Ibn Sinnā and Cheselden are different, they have the common principle that the whole is other than the sum of the parts. For Ibn Sinnā, this was the function the parts have in contribution to the organism as a whole; as for Cheselden, this was structural patterns shared by the parts in constituting a perfect whole.

The principles discussed above provide us with the framework to compose the whole not just by summing up the parts, but through constructing structural patterns between the relational parts. Cheselden's attempt, which is rooted to notion of wonder in Enlightenment, to represent the human body perfectly required the usage of the patterns of visual perception. For, perception of a figure is the filtering process of the perceiver that operates through intermingled processes of sensation and perception; and without the usage of these structural

50 Paula Findlen, 2010, https://web.stanford.edu/class/history13/earlysciencelab/main/index.html.

51 K. H. Keskinbora, et. al. A systematic review of Ibn Sīnā's studies: reflections on anatomy, European Journal of Anatomy 20 (1) (2016): 99-100, p.99.

52 K. H. Keskinbora, et. al. A systematic review of Ibn Sīnā's studies: reflections on anatomy, European Journal of Anatomy 20 (1) (2016): 99-100, p.99.

53 K. H. Keskinbora, et. al. A systematic review of Ibn Sīnā's studies: reflections on anatomy, European Journal of Anatomy 20 (1) (2016): 99-100, p.99.

54 K. H. Keskinbora, et. al. A systematic review of Ibn Sinnā's studies: reflections on anatomy, European Journal of Anatomy 20 (1) (2016): 99-100, p.99. 
patterns bones of the human body would not constitute a whole. In this regard, human skeleton is considered to be the structural element of such a perceptual filtering for human body. Although the human body is represented as a whole in the Plate 36, among many others in the work of Cheselden, relation of the parts is the crucial notion to come up with a meaningful whole. This brings the discussion to the Gestaltian statement that "the whole is other than the sum of its parts".

\section{Whole and Parts}

Gestalt is a German word that can be translated to mean form, whole, or even whole form as "a result of the basic observation that elements within a pattern do not seem to operate differently". ${ }^{55}$ Actually, this can be interpreted as a reflection of the influence of Newtonian thought (which is also influential on Enlightenment thinking) on the Gestaltian maxim that "the whole is other than the sum of its parts". For, this maxim presupposes that "there appear to be attractive forces among the various elements that cause them to form a meaningful and coherent figure, much as gravity organizes the planets, sun and means of the solar system". ${ }^{56}$ In Newtonian physics, it is the notion of gravity that explains the organization of planets, which enables a holistic explanation of the operation of universe. As for the perception (of a figure), it is the structural patterns that explain the organization of sense data to come up with a meaningful percept.

It is reasonable to argue that the unification of parts takes shape according to the relational principles that are present in the visual field. The rationale behind this claim is the argument that "all reality is structured, formed and patterned with highly concrete total attributes and invariably obeys the law that total processes define what shall take place in subordinate areas". ${ }^{57}$ In this regard, a salient example can be demonstrated by arguing that "human brain is structured to deal with the holistic properties of the stimulus, such as configuration, symmetry and closure of a visual form" ${ }^{58}$ A perceptual object is then conceived as some kind of whole, consisting of a structure that is not the same as the set consisting of the nonrelational parts of a structure; rather as a holistic unit consisting of relational parts. ${ }^{59}$ Thus, relational elements enable these parts to be a whole, which is something more than the sum of them.

Cheselden's work 'The Anatomy of Bones' is a case in point on the discussion of whole and part since human body, which consists of parts as well, is the perceptual object in his work. As a visible natural whole that is made up of bones (which are revealed through the illustration of skeletons), the human body is "the organic paradigm or architectonic standard for all complex unions". ${ }^{60}$ Thus, relational

\footnotetext{
S. Coren, Sensation and Perception, (Fort Worth TX: Harcourt Brace Colleague Publishers, 1994), 380. S. Coren, Sensation and Perception, (Fort Worth TX: Harcourt Brace Colleague Publishers, 1994), 381. G. W. Hartmann, Gestalt Psychology, (New York: The Ronald Press Company, 1935), 65.

58 K. R. Boff, et. Al. (eds.), Handbook of Perception and Human Performance, (New York: Wiley, 1986), 367.

59 R. Grossmann, The Philosophical Background of Gestalt Psychology, Critica (9): 24 (1977: 3-21, p. 7.

60 B. M. Stafford, Body Criticism: Imaging the Unseen in Enlightenment Art and Medicine, (Cambridge: MIT Press, 1993), 12.
} 
patterns of grouping by similarity, contrast and symmetry constitute the human body as a visual field to investigate. If these patterns were not applicable to human body, then it would not be possible to conceive human body as a whole.

In that case, it would be only a summing of some parts into a unit that does not form a meaning contrary to the statement of Chesleden that "every bone in the human body is delineated as large as the life, and again reduced to lesser scales in order to show them united to each other". In this regard, visual elements reflect the relationship between the form and meaning. For, "the true shape of an object (human body in this case) is constituted by its essential spatial features". ${ }^{61}$ These features are reinforced by the structural patterns of the visual field, yet otherwise summing up these features would be a meaningless procedure. Therefore, the perception of human body as a figure is a constant result of the perpetual filtering process that combines the sense data into a meaningful whole according to the principles of simplicity.

In this regard, the role of kalam can be disclosed as a question with regards to the meaning attached to human body and how to approach it. Kalam can be situated in its full intellectual historical context as "a systematic theocentric scientific research program possessing of objective cognitive content" in the sense that "it is about understanding God, on the one hand, and on the other, it is concerned with understanding Creation". ${ }^{62} \mathrm{Al}-\mathrm{G}$ hazālī also mentions the origins of such inquiry in the works of one type of group of philosophers he calls Ta'biyyun:

A body of philosophers who have engaged in manifold researches into the world of nature and the marvels of animals and plants and have expended much effort in the science of dissecting the organs of animals. They see there sufficient of the wonders of God's creation and the inventions of His wisdom to compel them to acknowledge a wise Creator Who is aware of the aims and purposes of things. No one can make a careful study of anatomy and the wonderful uses of the members and organs without attaining to the necessary knowledge that there is a perfection in the order, which the framer gave to the animal frame, and especially to that of man. ${ }^{63}$

Although Al-Ghazāli criticizes them on the basis of their conception with regards to the soul, according to the new Ottoman scientists of Kalam, "the issues related to the authentic nature of the soul, or whether it exists independently of the human body, cannot be known assertively". ${ }^{64}$ In this regard, it is congruent to claim that the new Ottoman scientists of Kalam were attempting to initiate a TheologicScientific research program. In such a program, the rational mind oscillates between the two axes of being: "one absolute, the other contingent, relating one to

61 R. Arnheim, Art and Visual Perception: A Psychology of the Creative Eye, (California: UCP, 1974), 38.

62 A. Setia, "The Theologico-Scientific Research Program of the Mutakallimun: Intellectual Historical Context and Contemporary Concerns with Special Reference to Fakhr Al-Din Al-Rāzī", Islam and Science 3(2) (2005): 127-151, p. 127.

63 W. M. Watt, The Faith and Practice of Al-Ghazālì. (Oxford: One World Publications, 2007), 23.

64 M. Bulgen, Osmanli Yeni Ilm-i Kelaminda Materyalizm Elestirileri, Bilimname XXX: (1) (2016): 391433, s. 424, translation is mine. 
the other and integrating them within the framework of a comprehensive and coherent Qur'anic worldview".65 For, the new Ottoman scientists of Kalam considers "the issues related to the nature of soul and whether it is material or not, as contingent issues, which is not related to the necessities belonging to the religion (the fundamentals of faith) or the tenets of Islam". ${ }^{66} \mathrm{It}$ is also significant to note that "the new Ottoman Mutakallimuns' dualist conception of human being is deeply rooted in Muteahirrun Mutaallimuns such as Al-Ghazālī and Fakhr al-din alRāzī" ${ }^{67}$ This is particularly interesting when we consider the fact that Fakhr al-din al-Rāzī devoted a significant part of his theological treatise to the descriptions of human body. ${ }^{68}$ For, this reflects the origins of theologico-scientific agenda of the new Ottoman scientists of Kalam were deeply rooted in the Islamic Golden age conception, where anatomy had been interlaced with theology.

Thereby, although it is not possible within the limits of this article, it would be fruitful to analyse how the perpetual filtering in a theologico-scientific programme would operate in Ottoman anatomical studies in terms of revealing its theoryladenness to the agenda of the new Ottoman scientists of kalam.

\section{Conclusion}

This paper has used Cheselden's 'The Anatomy of Bones' to reinforce the claims that the way a figure seen is influenced by the visual field. I have argued that in the eighteenth century, this visual field is eclipsed by the principles of similarity by grouping and symmetry. Moreover, I have demonstrated that perception is a result of this grouping, which is the filtering of sense data (namely products of seeing in this case) into a meaningful whole (human body). In order to demonstrate this, firstly, the interpenetrating relationship between the processes of sensation and perception has been analysed. I have shown that organization of sense data is realized in the simplest manner available in the prints drawn by Chelselden. Moreover, it has been shown that human body would be perceived as a meaningful whole palpably by the reinforcing visual principles rather than as a sum of bones and flesh. Finally, it has been concluded that human body and thereby Cheselden's illustrations can be perceived in their unity and this enables the viewers to attribute a meaning to the figures they see in the illustrations. I have referred to Ibn Sinnā's descriptions of human skeleton, in their attempt to disclose their function, to demonstrate the difference in the principles that determine the nature of illustrations.

65 A. Setia, "The Theologico-Scientific Research Program of the Mutakallimun: Intellectual Historical Context and Contemporary Concerns with Special Reference to Fakhr Al-Din Al-Rāzī", Islam and Science 3(2) (2005): 127-151, p. 127.

66 M. Bulgen, Osmanli Yeni Ilm-i Kelaminda Materyalizm Elestirileri, Bilimname XXX: (1) (2016): $391-$ 433, p. 423 , translation is mine.

67 M. Bulgen, Osmanli Yeni Ilm-i Kelaminda Materyalizm Elestirileri, Bilimname XXX: (1) (2016): 391433, p. 423, translation is mine.

68 M. M. Shoja, M. M., \& Tubbs, R. S.. The History of Anatomy in Persia. Journal of Anatomy, 210(4), (2007), 359-378, p. 363. http://doi.org/10.1111/j.1469-7580.2007.00711. 
By way of conclusion, it can reasonably be stated that in the era of Enlightenment meaning is communicated through the graphic techniques. This statement shows parallelism with the claim that graphic technique is a tool of the scientific illustration. This essay has demonstrated that Cheselden used the graphic technique to come up with a comprehensive conception of human anatomy aimed at perfection. Thus, it can be concluded that rather than using long descriptions and arguing in favour of these descriptions, Cheselden made use of principles of simplicity - which depends on the structural features of objects such as direction, shape, shade, and proximity - and symmetry to attribute a unity and perfection to the figure of human body. It has also been argued that the main thesis of this article can also be applied to a comparative case-study between Cheselden and Ottoman anatomists, which might be provide the readers with an interdisciplinary study.

\section{References}

Arnheim, R. Art and Visual Perception: A Psychology of the Creative Eye. California: UCP, 1974.

Batirel, H. F. "Early Islamic Physicians and Thorax". The Annals of Thoracic Surgery 67 no. 2 (1999): 578-580.

Boff, K. R et. al. (eds.). Handbook of Perception and Human Performance. New York: Wiley, 1986.

Bulgen, M.. “Osmanli Yeni Ilm-i Kelaminda Materyalizm Elestirileri”, Bilimname XXX, no. 1 (2016): 391-433.

Cheselden, W. Osteographia, or The anatomy of the bones. By William Cheselden surgeon to Her Majesty; F.R.S. Surgeon to St. Thomas's Hospital, and Member of The Royal Academy of Surgery. London : [s.n.], MDCCXXXIII, 1733.

Coren, S. Sensation and Perception. Fort Worth TX: Harcourt Brace Colleague Publishers, 1994.

Ford, B. Images of Science: A History of Scientific Illustrations. London: British Library, 1992.

Ford, B. Scientific Illustration in the Eighteenth Century, R. Porter (ed) The Cambridge History of Science vol. 4 Eighteenth Century. Cambridge: Cambridge University Press, 2003.

Grossmann, R. "The Philosophical Background of Gestalt Psychology". Critica 9 no. 24 (1977): 3-21

Harrison, B. and Matthew, H. C. G. (eds.). Oxford Dictionary of National Biography. Oxford: Oxford University Press, 2004.

Israel, J. I. 'Enlightenment, Radical Enlightenment and the Medical Revolution of the Late Seventeenth and Eighteenth Centuries', O P Grell (ed) Medicine and Religion in Early Modern Europe. Hampshire: Ashgate, 2007. 
Hartmann, G. W. Gestalt Psychology. New York: The Ronald Press Company, 1935.

Ibn Sīnā. A treatise on the Canon of medicine of Avicenna, incorporating a translation of the first book. London :Luzac \& co., 1930.

Keskinbora, K. H. et. al. "A systematic review of Ibn Sīnā's studies: reflections on anatomy". European Journal of Anatomy 20 no.1, (2016): 99-100.

Knoeff, R. 'Moral Lessons of Perfection', O P Grell (ed) Medicine and Religion in Early Modern Europe. Hampshire: Ashgate, 2007.

Norman, J. M. (ed). Morton's Medical Bibliography: An Annotated Checklist of Texts Illustrating the History of Medicine. $5^{\text {th }}$ edition. Aldershot: Scholar Press, 1991.

Prioreschi, P. “Anatomy in Medieval Islam”. JISHIM 5 (2006): 2-6.

Roberts, K. B. The Fabric of the Body. Oxford: Clarendon Press, 1990.

Setia, A. "The Theologico-Scientific Research Program of the Mutakallimun: Intellectual Historical Context and Contemporary Concerns with Special Reference to Fakhr Al-Din Al-Rāzī", Islam and Science 3 no.2, (2005): 127-151.

Shoja, M. M., \& Tubbs, R. S. "The History of Anatomy in Persia". Journal of Anatomy, 210 no.4, (2007), 359-378. http://doi.org/10.1111/j.14697580.2007.00711.

Slater, A. and Oates, J. 'Sensation to Perception', in Oates, J. Grayson A. and Wood C. (eds.) Psychological Development and Early Childhood. Milton Keynes: Open University Press, 2005.

Stafford, B. M. Body Criticism: Imaging the Unseen in Enlightenment Art and Medicine. Cambridge: MIT Press, 1993.

Trevsky, B. "Visualizing Thought". Topics in Cognitive Science 3 no.3, (2010): 499535.

Watt, W. M. The Faith and Practice of Al-Ghazālī. Oxford: One World Publications, 2007. 